\title{
Investment in Conventional or Renewable Energy Sources: Thyssengas - A Green Energy Provider?
}

\author{
Tomasz Bernat \\ Dr hab., University of Szczecin, Faculty of Economics and Management, \\ Department of Microeconomics
}

\section{Introduction}

Pro-environmental business activity takes different forms. One of them is a complex approach to technological progress aimed at increased involvement in environmental protection. As an example of such an attitude this paper presents Thyssengas, the leading natural gas supplier in Germany. The technological solutions described below combine conventional energy sources with the renewable ones. This shows that even in large-scale business activity economic entities can use pro-environmental methods by changing their basic technology.

\section{The Objectives and the Methodology}

Companies operating in market economies often make efforts intending to show their best side to stakeholders. One such endeavor is involvement in promoting environmentally friendly solutions. In the majority of cases such initiatives are undertaken by large and very large businesses as they can allocate adequate financial resources and assign staff to dedicated organizational units. Such activity is closely related to public relations because its main objective is to give the company a positive image. Moreover, businesses initiate real actions

How to cite this book chapter:

Bernat, T. 2019. Investment in Conventional or Renewable Energy Sources:

Thyssengas - A Green Energy Provider? In: Gąsior, A. (ed.) Pro-ecological

Restructuring of Companies: Case Studies, Pp. 63-73. London: Ubiquity Press.

DOI: https://doi.org/10.5334/bbk.f. License: CC-BY 4.0 
associated with organizational, technological, structural or financial changes. Such activities can be referred to as operational restructuring that is aimed at implementing pro-environmental or CSR-related solutions.

The above concept is exemplified by the activities initiated by the object of the present analysis, namely Thyssengas GmbH. It is one of the leading economic entities in Germany. Its main field of operation is transporting natural gas to individual and industrial customers. Here, several elementary questions arise regarding whether businesses in this particular sector are able to introduce environmentally friendly solutions on a large scale. If they are able to do so, how is this performed and what are the benefits for the company, its customers, the economy in general and for the society? Such posed questions allow for the hypothesis that a natural gas supplier is able to implement cutting-edge pro-environmental technology on a large scale.

In order to verify the above hypothesis, we need to examine the company history together with the changes to its profile, technological advancement and the environmental impact on its operation. The major research method is the analysis of source documents and literature. Then, based on these findings, the company operation will be evaluated in the context of the technological changes. Finally, the conclusions of the analysis will be presented.

\section{Company Performance and History of Activities}

Thyssengas $\mathrm{GmbH}$ is an independent network operator and one of the leading German natural gas transport network companies. It was founded in 1921 and operates Germany's first long- distance gas pipeline (from Duisburg-Hamburg to Wuppertal-Barmen), which was built in 1910. Today, Thyssengas is an independent "carrier" for national and international natural gas trading companies. Its transport system extends from wide areas of North-Rhine Westphalia to Lower Saxony. Natural gas is transported safely and in an environmentally friendly way from the state borders to the centres of consumption and to the natural gas storage facilities. Thyssengas independently transports up to 10 billion cubic metres of natural gas via 4200 kilometres of underground transmission pipelines.

The company has a long-standing history, employs thousands people, and realizes its allowed revenues largely under the regulation of the German Federal Network Agency (Bundesnetzagentur). All functions of traditional gas transport are supplemented by adding new service offerings. Tasks range from transport capacity booking to constant analysis of natural gas fed in by natural gas traders, which is necessary for consumer protection.

With its current and potential new partners, Thyssengas takes an active part in shaping the future by developing and expanding the NCG market area in the long run in order to make it one of the most liquid gas markets in Europe. In 2016 Thyssengas was acquired by the consortium DIF Infrastructure IV and 
EDF Invest, as equal shareholders. The agreement of the Thyssengas acquisition takes under consideration that a German gas transportation network belongs to the company.

Regarding the situation in Germany, the demand for energy and competition continue to grow. Thus, active participation in the gas transport market and permanent improvement of natural gas logistics are at company's centre of attention. This is the reason that Thyssengas has joined NetConnect Germany (NCG), the largest market area in Germany, which links the former $\mathrm{H}$ - and L-gas market areas of six transport network operators with connection points to more than 500 distribution networks.

\section{Investments in Renewable Energy - Europe and Germany}

The importance of renewable energy sources has been increasing in every country all over the world (Schweitzer and Persson 2014). This can be seen in particular in highly developed countries. Germany is a leader in implementing such solutions (Biogazownie na Świecie 2017). Politicians develop a vast range of economic or social policies supporting and encouraging both individuals and organizations to initiate environmentally friendly activities (Bartosik 2007). Funds spent on renewable energy sources are growing year by year, reaching record levels. According to Raport (Raport 2016), global expenditure on investments rose by 5\% in 2015, attaining USD 285.9 billion worldwide. Global expenditure on those investments from 2004 to 2015 is shown in Figure 1.

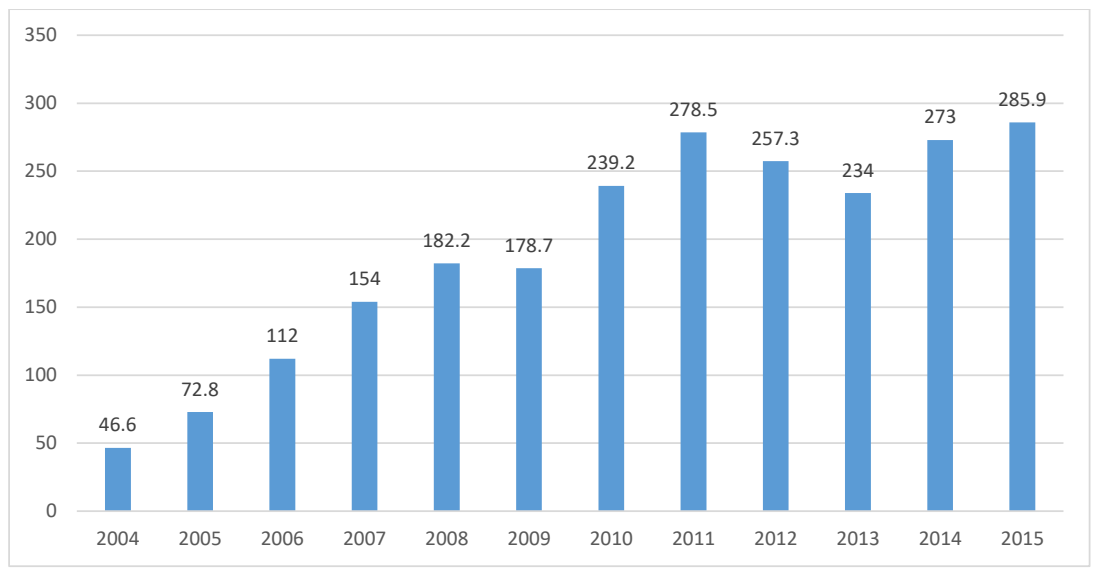

Fig. 1: Global expenditure on new investments in renewable energy in 20042015 in billions of US dollars.

Source: UNEP, Bloomberg New Energy Finance. 


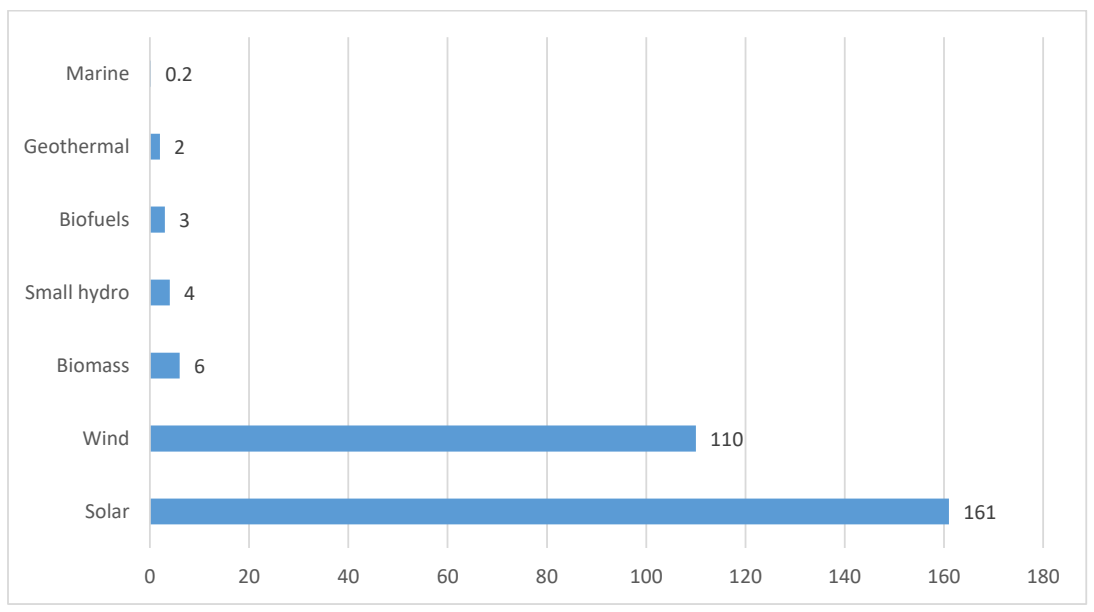

Fig. 2: Global investment in renewable energy by sectors in 2015 and in billions of USD.

Source: UNEP, Bloomberg New Energy Finance.

When looking at the chart, it should be noted that over the observed period the expenditure rose more than six times, from 46.6 to 285.9 billion US dollars. Additionally, when analyzing the data in developed and developing countries, a steadily accelerating upward trend can be seen in the latter. In the record year of 2015, the investments in green energy in the developing countries were higher than in the developed ones (156 and 130 billion US dollars respectively).

To assess the growth of green energy market, we should look at its individual sectors. The two leading ones that attracted the most investment in 2015 were solar technology (photovoltaics) and wind farms (see Figure 2).

Figure 2 shows the distribution of new investments in renewable energy. As seen from the diagram, there were two dominating sectors, namely solar and wind energy technologies. The remaining sectors did not attract significant investment. Interestingly enough, in comparison to 2015, the major increase in investments was seen in solar energy technologies, while the other sectors, excluding wind power, experienced declines. In conclusion, in 2015 the major sector that pulled this part of the world economy upwards was solar technology, primarily due to the fact that it provides solutions that generate cheap electric power (DOE 2011).

Another interesting fact concerns the countries that invest the most in renewable energy. In 2015, the biggest spenders were China (more than 102.9 billion US dollars) and the USA (USD 44.1 billion). In Europe it was the United Kingdom that spent the most (USD 22.2 billion), followed by Germany (USD 8.5 billion).

Germany is the sixth global leader in investments in renewable energy. It started the energy revolution by investing enormous amounts of money for 
that purpose. Over the past decade "green" politicians, supported by ecologically aware voters, decided to move on to a green energy transition, called Energiewende in German. They offered substantial subsidies for those who decided to invest in green energy sources, which considerably increased public involvement in solar and wind technologies (formerly regarded as a niche market), thus contributing to their lower manufacturing costs. As a consequence, they gained a competitive edge in relation to fossil fuels (Ball 2017). The major elements of that revolution were both an increased involvement in the production and use of solar and wind energy, as well as the change in approach of companies selling such conventional fuels as natural gas. A good example of this is Thyssengas, a German trader and distributor of natural gas.

\section{Thyssengas - On the Path to Change}

Rapidly changing global energy markets are facing challenges that force them to change (Valladares and Jensen 2011). The challenges result from growing consumers' awareness, new and innovative technological solutions as well as from the increasingly better quality of products and services (Schweitzer and Formanski 2017). However, the major challenges are environment-oriented requirements that companies must comply with. This also refers to energy traders, such as Thyssengas. As mentioned above, Thyssengas is a leader in the German gas distribution market. It annually transports over 10 billion cubic meters via 4200 kilometers of its own pipelines.

Despite the gas supply, the main responsibility of the company is to ensure that the gas is transported safely, both in terms of the risk of system failure and its consequences, and that its supply to the customers is uninterrupted. What is nevertheless important for the company itself and for German society is such business operation that does not pose a threat to the natural environment. The pipeline failure or possible consequences of gas leak or explosion cause not only material damage for the company and the society, but also result in substantial environmental costs. Therefore, the company has to guarantee proper functioning of its systems in every aspect. At the same time, whenever it is technically possible, the company should participate in efforts to maximize the use of renewable energy sources. Such operational restructuring means that the offer should be supplemented with a whole range of biogases that can be produced as fuels coming from renewable energy sources. The answer to the question of how these goals are being met is to be found further in this work.

\section{Safety of natural gas transmission}

Safe transmission of natural gas is one of the essential objectives of every economic entity dealing with such services (Wit 2006), such as Thyssengas. 
One of the mottoes incorporated in the company mission is: Energy reaches its goal safely and pollution-free. To this end Tyssengas joined NetConnect Germany (NCG) with the intention of proactively shaping its future and optimizing the logistics of natural gas transmission in response to the consumers' expectations. Today, the company's plans include even closer cooperation with natural gas suppliers and new consumers for the benefit of further growth of the NCG market in Germany and building such a market in Europe. Such market consolidation creates the opportunity to expand the offer for customers, add new options and promote competitiveness in the area.

It is important to mention other members of NetConnect Germany: Bayernets GmbH, Eni Gas Transport Deutschland S.p.A., Open Grid Europe, GRTgaz Deutschland GmbH and GVS Netz GmbH. These business partners ensure both safe transmission of natural gas and a broad range of services encompassing trading with gas and supplying it to consumers (Wit and Andersen 2012). These services include: accounting grid management, the provision and operation of a virtual trading point, the online provision of data relating to settlement and balancing energy, and balancing energy management.

Such a solution permits the otherwise difficult combination of services: the comprehensive availability of an energy source and transport channels that are extremely reliable and pollute neither rivers nor roads. Safety and environmental protection procedures are incorporated in all Thyssengas organizational procedures. Every activity addresses security and environmental challenges. In this sense, the creation of the European natural gas grid is an investment in a cutting-edge, effective and safe system of gas transmission that has not been possible before on such scale. One of its basic elements is building new pipelines that will make it possible to include diverse energy sources, both renewable and non-renewable, in the system. This solution secures a reliable and uninterrupted gas supply.

Pipelines built by Thyssengas comply with the highest international and German legal requirements that meet the consumers' increasing expectations regarding the transmission safety and the network accessibility. For instance, new natural gas plants and pipeline systems, such as five new facilities located in North-Rhine Westphalia and connecting the German system with the Dutch grid, or a new facility in Saxony-Anhalt that offers the opportunity to better adjust to the local customers' needs are all built in accordance with the latest trends in technology in terms of security, functionality or strength of the safety equipment. All these initiatives are always inspected by independent security consultants.

How is the operational activity of the company monitored? All the pipelines are regularly inspected and analyzed for safety by a helicopter. The main purpose of these inspections is to assess if new construction projects in the proximity of a pipeline are not a threat to their safety. When problems are detected, measures are taken in order to neutralize the risk. 
One serious risk to pipeline safety is uncontrolled gas leaks. In such a case, preventive steps include specialist checks for leakage and emergency shut-off systems. To this end, ultramodern methods such as intelligent pigs are used to react instantly to the detected leakage and to initiate maintenance and repair works. What poses an additional problem is the very nature of the material of which pipelines are made. Metal, being a basic component of pipes, is subject to corrosion. Therefore, a special electric anticorrosion system is installed (Spiegelhauer, Persson and Kildsig 2017).

In general, the safety of the network is monitored from a central control desk in Dortmund that focuses mainly on the pipeline pressure and quality. The around-the-clock service is ready to react immediately to emergency situations and to start repair works.

Furthermore, it is worth mentioning the measures regarding direct protection of the natural environment. Thyssengas incorporated the need for environmental protection in all its operational plans. New building works needed to expand transmission grids are designed along with protective measures. When a new pipeline is laid, its natural environment is restored to a state that is not worse than before the works. What is more, decisions are made to leave it in an even better condition. Once the investment has been completed, the pipeline can only be traced by special signposts.

\section{Combining renewable and non-renewable energy sources}

One of the elementary opportunities offered by modern technology is the combination of conventional and renewable energy sources. In reference to Thyssengas this means the possibility of mixing natural gas with biogas. It is known that the use of biogas helps to prevent climate change. It can be utilized in almost every aspect of business activity.

Special generators are used to feed biogas in the natural gas grid, thus creating a more environmentally friendly product. Such technology is both economically sound and effective. For instance, this product can be used to generate electricity or heat new facilities. This creates new opportunities to improve the cost-effectiveness of biogas generators.

Thyssengas has developed technology for feeding biogas into natural gas pipelines and supplying the mixture to consumers. The simplified process is shown in a Diagram 1 below.

Diagram 1 shows the technology used to transmit natural gas mixed with biogas to consumers. Apart from natural sources of biogas produced from agricultural waste, the technology obtains electricity from renewable energy sources (Kostowski and Górny 2010). The technology allows the use of biogas as fuel for gas cogeneration systems in the scattered power industry (combined production of electric power and heat) and allows for heating inside areas by means of gas-fired boilers or heating food on gas cookers. The importance 


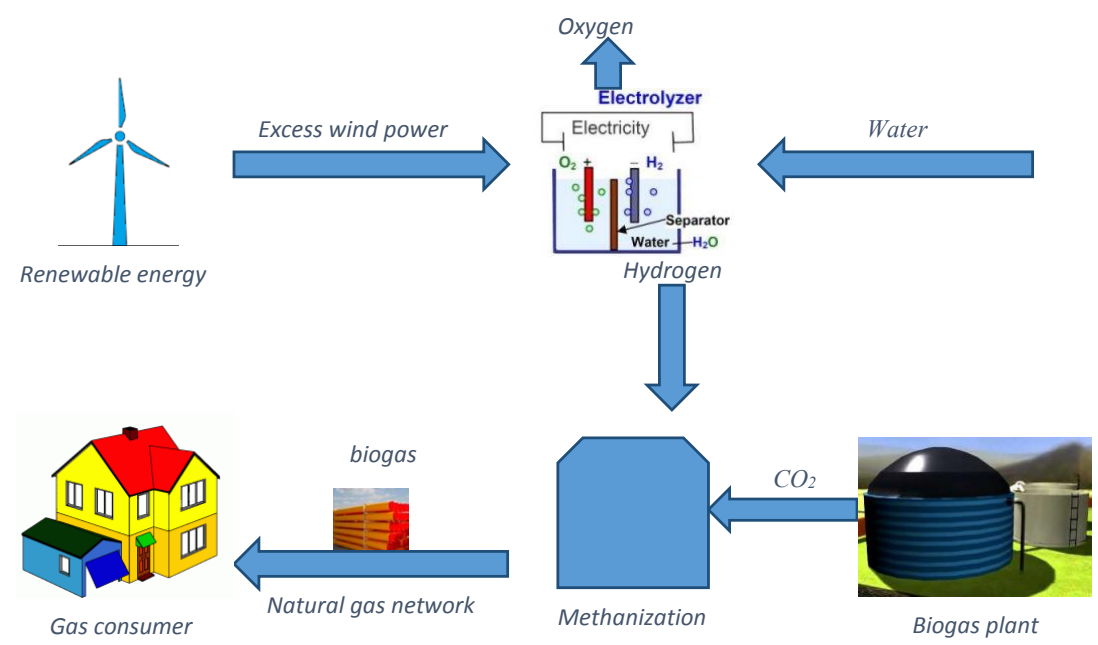

Diagram 1: Thyssengas technology to produce, mix and supply biogas to consumers.

Source: http://www.thyssengas.com/en/biogas/.

of these methods is growing because due to gradual depletion of natural gas deposits, it will become necessary to mix it with biogas. However, there are several serious problems that either have been already solved by modern technology or will be addressed in the near future.

The elementary issue is the process of biogas refining followed by its conversion in order to meet specified calorific and technological parameters according to the quality standards of mains gas. The conversion process is usually based on $\mathrm{CO}_{2}$ water absorption (see Diagram 1), but other methods are applied as well. Another problem arises when it comes to feeding biogas into natural gas grids, as it must be scrubbed of harmful components (such as sulphur compounds, carbon monoxide, water vapor or oxygen). There is also a question of whether biogas should be upgraded, which means scrubbing it of carbon dioxide and nitrogen, thus obtaining higher or lower calorific value in comparison to mains gas. The next important issue is the location of the existing biogas plants, which should be situated near transmission and distribution grids.

According to Jonasson et al. (2003), Skorek and Kalina (2005), Dupoint and Acrosi (2006), Rasi et al. (2007), Barczyński (2009), and Kostowski and Górny (2010), it is possible to mix biogas with natural gas while keeping certain standard parameters. Basing on findings concerning the high-methane gas (E), the infusion of 5-10\% of low-methane biogas allows for maintaining appropriate fuel quality. In practice, this proportion has been tested in solutions developed by Thyssengas. However, the company itself points to the following several technical complications: 
- a problem with achieving adequate calorific value of biogas that would correspond to the natural gas quality. It is a condition of generating a high quality end product.

- a problem with high sensitivity of the technological system to the fluctuations in the quality of natural gas and biogas. These factors both affect the efficiency of the machinery and pollute the natural environment.

- a problem with the end quality of the product as stipulated by the calibration law. Consumers should always receive the product of the same quality, which is difficult to obtain when two gases are mixed.

\section{Thyssengas - A Greening Company}

The activity of the leading gas supplier on the German market demonstrates the opportunities provided by renewable sources of energy. The elementary questions to be answered in this part of the paper have been as follows:

- Is it possible for a business entity operating in this particular economy sector to implement ecological solutions on a large scale?

- How does it happen and what are the benefits for the company, its customers, the economy and society?

The following research hypothesis was made: A company dealing with natural gas supply is able to implement a cutting-edge biogas technology on a large scale.

The study results provide answers to the questions above as well as positive verification of the hypothesis. The example of Thyssengas $\mathrm{GmbH}$ proves that even a massive scale of operation does not constitute a barrier to implementing technological and practical solutions related to the use of renewable energy sources. Despite diverse technological or legal problems, the technology of mixing natural gas with biogas allows for greening the end product and its extensive economic use.

What benefits are gained? First of all, any business in the natural gas transmission sector is able to incorporate the latest solutions into its operation. This will be advantageous not only for the company itself (e.g. company promotion, good PR, competitive edge and research into the technology of the future), but for society in general (green solutions, reductions of environment pollution, reliable product suppliers). Additionally, the fact that the companies from this sector have created a Union-wide network allows for the assumption that the range of their impact can be wider than just one country.

In conclusion, the hypothesis that a company dealing with natural gas supply is able to implement a cutting-edge biogas technology on a large scale has been verified. This conclusion has been supported by the results of the analysis of Thyssengas $\mathrm{GmbH}$ operation. The impact of the solutions implemented by the company has been highly rated. 
The technologies that have been used by the natural gas and biogas providers allow us to draw several conclusions. The gas market is constantly evolving, which is due to both natural and political or social factors. The use of modern technology ensures the greening of businesses and transforming a conventional product into an innovative solution that meets the society needs on an increasingly high level. Therefore, we can expect more revolutionary technological solutions employing renewable energy in our everyday lives.

\section{References}

Ball, J 2017 Germany's High-Priced Energy Revolution, Fortune 2017. Available at http://fortune.com/2017/03/14/germany-renewable-clean-energy-solar/ [Last accessed 15 Nov 2017].

Barczyński, A 2009 Wprowadzanie biogazu do systemu dystrybucyjnego - szanse i możliwości. Materiały konferencji „Rynek Gazu”.

Bartosik, M 2007 Globalny kryzys energetyczny - mit czy rzeczywistość? Wybrane możliwości działań antykryzysowych w elektrotechnice. "X Międzynarodowa Konferencja „Nowoczesne urządzenia zasilające w energetyce" Zakopane.

Biogazownie na Świecie 2017 Available at http://ioze.pl/energetyka-biogazowa/ biogazownie-na-swiecie [Last accessed 17 Nov 2017].

Borbely, A-M and Kreider, J F 2000 Distributed Generation The Power Paradigm for the New Millennium. Boca Raton, Florida: CRC Press.

Dupont, L and Accorsi, A 2006 Explosion characteristics of synthesised biogas at various temperatures. Journal of Hazardous Materials, BI 36.

Gorzelik, J 2010 Nowe przepisy dotyczace biogazu i biogazowni w kontekście zmian $w$ prawie energetycznym. Available at http://www.cire.pl/item,50712, 14,0,0,0,0,0,nowe-przepisy-dotyczace-biogazu-i-biogazowni-w-konteksciezmian-w-prawie-energetycznym.html [Last accessed 17 Nov 2017].

Innogy Gas Storage. Natural gas storage of Innogy. Available at https://innogygasstorage-nwe.com/en/storage-marketing/capacities-and-booking [Last accessed 11 Sep 2018].

Jonsson, O Polman, E Jensen, JK Eklund, R Schyl, H Ivarsson, S 2003 Sustainable gas enters the European gas distribution system. Raport Danish Gas Technology Center. Available at www.dgc.dk/publikationer/konferen-ce/ jkj_sustain gas.pdf [Last accessed 17 Nov 2017].

Kostowski, W and Górny, K 2010 Analiza możliwości mieszania biogazu z gazem ziemnym $z$ uwzględnieniem limitów wymaganej jakości gazu sieciowego, Instal, $\mathrm{nr} 3$.

Rasi, S et al. 2007 Trace compounds of biogas from different biogas production plants, Energy 32. 
Schweitzer, J and Formanski, T 2017 Toward New Technologies for the Gas Market. Available at http://www.dgc.eu/sites/default/files/filarkiv/documents/ A0811_new_gas_technologies.pdf [Last accessed 17 Nov 2017].

Schweitzer, J and Persson, P 2014 Do we need new gas technologies for the domestic and small commercial space heating market? Available at http:// www.dgc.eu/sites/default/files/filarkiv/documents/C1402_IGRC2014_ Schweitzer.pdf

Skorek, J and Kalina, J 2003 Gazowe układy kogeneracyjne. WNT, Warszawa 2005.

Spiegelhauer, B, Persson, P and Kildsig, M 2017 A Study of Corrosion in Balanced Flues Depending on Operation Conditions. Available at http://www. dgc.eu/sites/default/files/filarkiv/documents/C0302_corrosion_flues.pdf [Last accessed 16 Nov 2017].

Thyssengas. Thyssengas Biogas. Available at http://www.thyssengas.com/en/ biogas/ [Last accessed 17 Nov 2017].

Thyssengas. Thyssengas Info. Available at http://www.thyssengas.com/en/ infothek/\#power-to-gas [Last accessed 17 Nov 2017].

Valladares, M R and Jensen, J K 2011 A Global Perspective on Progress and Politics in R,D\&D Cooperation, 4th World Hydrogen Technologies Convention, 2011, Glasgow, U.K., Paper ID: 0099. Available at http://www.dgc.eu/sites/ default/files/filarkiv/documents/C1103_global_perspective_hydrogen.pdf [Last accessed 17 Nov 2017].

Waterleau. Waterleau selected as biogas plant commissioner for region's energy recovery transformation project. 2016. Available at http://www.waterleau. com/en/news-events/news/commissioning-of-new-biogas-plant-inbergheim-paffendorf [Last accessed 17 Nov 2017].

Wit, J 2006 Safety matters, experience with the operation of gas engine CHP units, Cogeneration and On-Site Production, September-October. Available at http://www.dgc.eu/sites/default/files/filarkiv/documents/A0613_safety_ matters.pdf [Last accessed 17 Nov 2017].

Wit, J and Andersen, S D 2012 Open gas markets, experience gained during gas import/export for gas fired CHP plants. Available at http://www.dgc.eu/ sites/default/files/filarkiv/documents/C1201_open_gasmarkets.pdf [Last accessed 17 Nov 2017]. 
